\title{
Selection Strategies for Grain Quality in Upland Rice Lines
}

\author{
Antônio R. Neto ${ }^{1}$, Douglas G. Castro ${ }^{1}$, Camila S. C. Da Silva ${ }^{1}$, Laís M. Tomé ${ }^{1}$, Priscila Z. Bassinello ${ }^{2}$ \\ \& Flávia B. S. Botelho ${ }^{1}$ \\ ${ }^{1}$ Agricultural Departament, Federal University of Lavras, Lavras, Minas Gerais State, Brazil \\ ${ }^{2}$ Brazilian Company of Agricultural Research (EMBRAPA), Goiania, Goiás State, Brazil \\ Correspondence: Douglas Goulart Castro, Agricultural Department, Federal University of Lavras, Lavras, Minas \\ Gerais, Brazil. Tel: 55-359-9153-8018. E-mail: douglasgoulartcastro@gmail.com
}

Received: November 22, 2018

Accepted: December 23, 2018

Online Published: February 15, 2019

doi:10.5539/jas.v11n3p443

URL: https://doi.org/10.5539/jas.v11n3p443

\begin{abstract}
The grain quality in rice is extremely important for breeding programs, in order to select lines that meet the standards demanded by the market. The quality attribute is composed by several characteristics, which can make difficult the work for breeder. Thus, the objective in this study was to verify the efficiency of the selection indexes in order to select upland rice lines that meet the grain quality standards. Fourteen lines of the Cultivation and Use Value test (CUV) of the upland rice breeding program of the Federal University of Lavras were evaluated. The experiments were conducted in the municipalities of Lavras-MG and Lambari-MG in the seasons of 2015/2016 and 2016/2017. The experimental was a randomized block design with three replications. The following characteristics were evaluated to compose the indexes: grain yield, minimum cooking time, water absorption index, grain chalkiness, integer grain percentage, grain length and width, apparent amylose content and gelatinization temperature. The following selection indexes were compared: Base index of Willians, Sum of "Ranks" of Mulamb and Mock, and Index Sum of Standardized Variables (Z Index) and also was held direct selection through grain yield. It was observed that the Base index obtained good gains with the selection for grain yield, but it was inefficient for the quality characteristics, results when used direct selection. The Ranks and $\mathrm{Z}$ index obtained superior and balanced gains for the characteristics, showing up more efficient in the selection of upland rice lines aiming at the quality of grains.
\end{abstract}

Keywords: Oryza sativa, multiple traits, plant breeding

\section{Introduction}

Rice is a major food grown and consumed worldwide, being the most important crop in many developing countries, feeding about half of the world population (United States Department of Agriculture - USDA, 2017). The quality of the rice grains is determinant to add value to the product and to the acceptance by the consumer and the industry.

The quality of grains in rice is focused on four main aspects: industrial quality, nutritional value, adequacy to commercial standards, and culinary and sensorial quality (Fitzgerald, Mccouch, \& Hall, 2009). These aspects are controlled by physicochemical factors that are fundamental for the knowledge of the characteristics of the rice grains after their preparation, assisting plant-breeding programs in the search for better cultivars.

In order to obtain such superior genotypes in relation to grain quality, considering physical, chemical, and industrial, it is important to evaluate a series of characteristics by using methodologies that can assist in the practice of simultaneous selection. The most used methodologies are: (i) Tandem, which is based on the selection of one characteristic at a time. However, this methodology is time consuming, expensive and of low efficiency; (ii) Independent Levels of Selection, which establish maximum and minimum levels. This methodology can lead to the exclusion of bad individuals in one specific characteristic, but good in others; (iii) Selection indexes, which gather the information of all the characteristics into a single value (Ramalho et al., 2012).

The selection index is a good alternative to combine the multiple values of different analyzed characteristics, so that the selection is made in a single value involving all characteristics on a set of variables that brings together several attributes of economic interest (Cruz, Regazzi, \& Carneiro, 2012). 
The first index was proposed by Smith (1936), in which the use of a selection index would be a simultaneous selection criterion for two or more correlated characteristics. It was later adapted to animal genetic improvement by Hazel (1943). The economic weights, genotypic and phenotypic variances for each trait, and genotypic and phenotypic covariates between each pair of traits are required (Freitas Junior et al., 2009). Afterwards, Williams (1962) proposed the Base index, in which the indexes are made by means of the linear combination of the average phenotypic values of the characteristics that are weighted by their respective economic weights. The index based on the sum of ranks proposed by Mulamba and Mock (1978) consists of classifying the genotypes in relation to each of the characteristics in descending order. Once classified, the orders of each genetic material referring to each characteristic are added (Freitas Junior et al., 2009). Furthermore, the $Z$ sum of the standardized variables ( $Z$ Index) in which the characteristics data are standardized with the intention of making them directly comparable, was also proposed (Nunes, Ramalho, \& Abreu, 2005).

Therefore, the purpose with this study was to evaluate the use of selection indexes for upland rice, aiming to select genotypes with high grain quality and comparing them with direct selection considering the productivity.

\section{Materials and Methods}

\subsection{Study Area}

The experiments were carried out in Lavras, at the Center for Scientific and Technological Development in Agriculture of the Federal University of Lavras, and in Lambari, Minas Gerais state, at the experimental farm of EPAMIG, during the 2015/2016 and 2016/2017 harvests.

\subsection{Genotypes}

Fourteen lines of the Cultivation and Use Value test (CUV) of the upland rice-breeding program of the Federal University of Lavras were evaluated (Table 1).

Table 1. Identification of the genotypes used in the study

\begin{tabular}{ll}
\hline Identification & Genotypes \\
\hline 1 & CMG 2162 \\
2 & CMG 2168 \\
3 & BRS ESMERALDA \\
4 & CMG 2170 \\
5 & CMG 2119 \\
6 & BRSMG CAÇULA \\
7 & CMG 2185 \\
8 & CMG 2187 \\
9 & CMG 2188 \\
10 & CMG 2085 \\
11 & BRSMG CARAVERA \\
12 & CMG 1511 \\
13 & CMG 1896 \\
14 & CMG 1509 \\
\hline
\end{tabular}

\subsection{Experimental Design}

The experiment followed a randomized block design with three replications. The plots consisted of five rows of four meters and the seeding density was 80 seeds per linear meter with spacing between rows of $35 \mathrm{~cm}$ and a useful plot area of $4.2 \mathrm{~m}^{2}$. Sowing was carried out between November and December in 2015 and 2016. The cultural practices were the same as those recommended for upland rice cultivation, except for the control of fungal diseases, since the program also evaluates resistance to disease.

The evaluated characteristics and their respective methodologies are described below:

(a) Grain Yield ( $\mathrm{kg} / \mathrm{ha}$ ): Obtained in grams per plot and converted to $\mathrm{kg} / \mathrm{ha}$, referring to the useful area of the plot eliminating the two lateral lines; 
(b) Integer Grain Percentage (\%): Percentage of whole grains resulting from the processing of rice grains. Samples $(100 \mathrm{~g})$ were processed immediately after harvested, threshing and drying in a mill (Susuki, model MT 10).

(c) Chalkiness (\%): Percentage of grains (white center) in samples of 100 milled grains of each plot. Each grain was classified as chalkined or no-chalkined, and the percentage of chalkined grains was counted.

(d) Apparent Amylose Content (AAC) (\%): The analysis was conducted at the Laboratory of Grains and By-products of Embrapa Rice and Beans by using a Foss Tecator FIA System (FIAStar 5000, Denmark) to determine the apparent amylose content. Rice samples, which were previously ground in a Perten Laboratory Mill 3100 mill, were injected after complete dispersion and gelatinization in alkaline solution, and the absorbance of the complex formed with iodine solution was determined in a UV-Visible spectrophotometer "Dual-Wavelength (DDW)" at $720 \mathrm{~nm}$. The amylose content of the samples was calculated based on a calibration curve prepared with preselected standard rice cultivars with known amylose contents determined by ISO 6647: 2007 Rice-Determination of amylose content of the International Organization for Standardization and classification followed the scale determined by Juliano (2003).

(e) Gelatinization Temperature (GT): Gelatinization temperature (GT) was determined in the Laboratory of Grains and By-products of Embrapa Rice and Beans, using a methodology adapted from Martinéz and Cuevas (1989). Ten grains (whole, healthy and polished) from each sample were evenly distributed on a $4.8 \mathrm{~cm}$ diameter plastic plate containing $10 \mathrm{~mL}$ of $1.7 \%$ potassium hydroxide solution $(\mathrm{KOH})$. Plates were capped and incubated in an oven (FISHER, model $255 \mathrm{G}$, Waltham, USA) at $30^{\circ} \mathrm{C}$ for 23 hours. The grains were classified according to a numerical scale of 1 to 7 . The average value of GT of each sample was obtained by multiplying the number of rice grains by the value of the corresponding degree of dispersion and then added and divided by ten.

(f) Cooking Test: It was carried out at the Grain Laboratory of the Department of Agriculture from the Federal University of Lavras. This study comprises several tests, which are carried out aiming to evaluate the behavior of the rice in the cooking process. The following tests were performed:

1) Minimum Cooking Time: A total of $5 \mathrm{~g}$ of whole rice were weighed and added in $135 \mathrm{~mL}$ of boiling distilled water. After 15 minutes, three grains were placed between two glass slides and these are compressed. This procedure was repeated at certain time intervals until the rice is cooked, which represents the complete gelatinization of the starch (Hummel, 1966; Ciacco \& Chang, 1986).

2) Water Absorption Index: A total of $5 \mathrm{~g}$ of whole rice that was cooked as previously described was drained and left for 5 minutes on absorbent paper so that the water present on the surface of the beans was discarded. Afterwards, the cooked grains were weighed and the water absorption coefficient was calculated (Donelly, 1979; Hummel, 1966).

(g) Grain Size: After processing, a subsample of 100 milled grains of each genotype was considered to obtain the images. The images were captured using a high-resolution camera and later the configuration of the Ground Eye was performed. For background color calibration, the values of luminosity, dimension "a", dimension "b", and grain size were adjusted according to the studied species. Biometric analyzes of the grains were carried out to obtain grain length (L) and width (W).

The grains were classified according to the standards defined by Brazil (2012) as: long-thin ( $\mathrm{L} \geq 6 \mathrm{~mm}, \mathrm{~W} \leq 2.17$ $\mathrm{mm}$, and $\mathrm{L} / \mathrm{W}>2.75)$, long $(\mathrm{L} \geq 6 \mathrm{~mm})$, medium $(\mathrm{L}<6$ and $\geq 5 \mathrm{~mm})$ and short $(\mathrm{L}<5 \mathrm{~mm})$.

\subsection{Statistical Analyzes}

Analyzes per environment were carried out for all the characteristics, involving all the places used in the experiment. The coefficients of variation and accuracy were used to determine the experimental accuracy. We also estimated the phenotypic correlations between the characteristics considering the average of the environments, according to the methodology of Ramalho et al. (2012). Analyzes were performed using the GENES software (Cruz, 2001).

\subsection{Selection Indexes}

Seven characteristics were study, excluding the amylose content and the gelatinization temperature since these characteristics are separated into classes and all the lines obtained the same classification. For all the characteristics, when necessary, the economic weight was considered one. A selection intensity of $25 \%$ was assigned on the lines for the evaluated characteristics, totaling four selected lines.

The following indexes were used:

(a) Base index of Williams (1962): 
For $\mathrm{n}$ characteristics, the base index is given by the following expression:

$$
\mathrm{I}_{\mathrm{W}(\mathrm{l})}=\sum_{\mathrm{k}=1}^{\mathrm{n}} \mathrm{u}_{\mathrm{k}} \overline{\mathrm{y}}_{\mathrm{ik}}=\mathrm{u}_{1} \overline{\mathrm{y}}_{\mathrm{i} 1}+\mathrm{u}_{2} \overline{\mathrm{y}}_{\mathrm{i} 2}+\ldots+\mathrm{u}_{\mathrm{n}} \overline{\mathrm{y}}_{\mathrm{in}}
$$

where, $I_{\mathrm{W}(\mathrm{i})}$ is the value of the base index associated with the individual/strain $\mathrm{i}$; $\mathrm{u}_{\mathrm{k}}$ is the economic weight of $\mathrm{k}$; $\mathrm{y}_{\mathrm{ik}}$ is the adjusted phenotypic mean of the individual/progeny i relative to the character $\mathrm{k}$.

The determination of the index values considering $\mathrm{n}$ characters for $\mathrm{v}$ genotypes can be performed in matrix form by the following expression:

$$
\mathrm{I}_{\mathrm{w}}=\mathrm{M} \times \mathrm{u}
$$

where, $\mathrm{M}$ is the matrix $\mathrm{v} \times \mathrm{n}$ of the adjusted phenotypic of $\mathrm{v}$ individuals/strain associated with $\mathrm{n}$ characteristics; $\mathrm{u}$ is the vector $\mathrm{n} \times 1$ of the economic weights associated with the characteristics.

(b) Index based on the sum of ranks proposed by Mulamba and Mock (1978):

The principle of the sum of ranks index is the transformation into poles of the adjusted phenotypic of the genotypes for each characteristic in order to increase or decrease phenotypic expression. The rank refers to the position or order. From the positions of the lines for each characteristic, the sum for each strain is obtained. The index for $\mathrm{n}$ characteristics is given by the following linear combination:

$$
\mathrm{I}_{\mathrm{MM}_{\mathrm{i}}}=\sum_{\mathrm{k}-1}^{\mathrm{n}} \mathrm{u}_{\mathrm{k}} \mathrm{r}_{\mathrm{ik}}=\mathrm{u}_{1} \mathrm{r}_{\mathrm{i} 1}+\mathrm{u}_{2} \mathrm{r}_{\mathrm{i} 2}+\ldots+\mathrm{u}_{\mathrm{n}} \mathrm{r}_{\mathrm{in}}
$$

where, $\mathrm{I}_{\mathrm{MM}_{\mathrm{i}}}$ is the value of the Mulamba and Mock index associated with the strain $\mathrm{i} ; \mathrm{u}_{\mathrm{k}}$ is the economic weight of the character $\mathrm{k} ; \mathrm{r}_{\mathrm{ik}}$ is the rank associated with the adjusted phenotypic of the strain $\mathrm{i}$ related to $\mathrm{k}$.

(c) Sum of standard variables (Z):

Characteristics data were standardized per plot using the following estimator:

$$
Z_{\mathrm{ijq}}=\frac{\mathrm{Y}_{\mathrm{ijq}}-\mathrm{Y}_{\mathrm{.qj}}}{\mathrm{S}_{. \mathrm{qj}}}
$$

where, $Y_{i j q}$ is the observation of the strain $i$ in the repetition $j$ for the character $q$;

$\mathrm{Y}_{\mathrm{.qj}}$ is the general average of the character $\mathrm{q}$ in the repetition $\mathrm{j}$; and $\mathrm{S}_{\mathrm{.qj}}$ is the phenotypic standard deviation of the character $\mathrm{q}$ in the repetition $\mathrm{j}$.

In order to avoid negative values, the constant four was added to the estimates, since the variable $Z_{\mathrm{ijq}}$ can have both positive and negative values. Thus, the population mean became four, instead of zero. After obtaining the values for the seven characteristics, the sum of the $\mathrm{Z}$ index was performed.

The GENES software (Cruz, 2001) was used to calculate the selection indexes. The index $(Z)$ was obtained using the Excel software (2007).

\subsection{Selection Gain Estimates}

After the establishment of the indexes, the selection gain in each evaluated characteristic was quantified for each index and for the direct selection. The estimate of the total gain was made by the sum of the gains of the individual characteristics. The expected gain for the character $\mathrm{j}$, when the selection is practiced on the index, is expressed by:

$$
\Delta \mathrm{g}_{\mathrm{j}(\mathrm{i})}=\mathrm{DS}_{(\mathrm{ji})} \mathrm{R}_{\mathrm{j}}
$$

where, $\Delta \mathrm{g}_{\mathrm{j}(\mathrm{i})}=\mathrm{g}_{(\mathrm{ii})}$ is the expected gain for character $\mathrm{j}$, with selection based on index I; $\mathrm{DS}_{(\mathrm{ij})}$ is the differential character; and $h_{j}^{2}$ is the repeatability of the character $\mathrm{j}$.

\subsection{Coincidence Index}

In order to evaluate the correspondence between the performances of the selected lines by the different selection indexes, the coincidence index was estimated, using the expression proposed by Hamblin and Zimmermann (1986):

$$
\mathrm{IC}=(\mathrm{A}-\mathrm{C}) /(\mathrm{M}-\mathrm{C}) \times 100
$$

where, $\mathrm{A}$ is the number of selected lines common to both selection strategies; $\mathrm{C}$ is the number of lines selected in the two selection strategies by chance. It is assumed that, from the number of selected lines, a proportion equal to the intensity of selection coincides by chance.

\section{Results}

Regarding the joint variance analysis, the experimental precision was good for almost all the characters with CV less than $20 \%$. Only the characteristic chalkiness showed high CV and lower experimental accuracy. 
There was a significant difference for all the characteristics, except for the water absorption index (Table 2). The interaction of genotypes by environments was significant for all the characteristics, indicating that the behavior of the lines differed in the four evaluated environments due to the different conditions in which the lines were exposed. There was no coincidence in the phenotypic expression of the genotypes.

Table 2. Summary of the joint variance analysis for: minimum cooking time (minutes), water absorption index, chalkiness (\%), integer grain percentage (\%), grain length and width (mm), apparent amylose content (\%), gelatinization temperature (scores) and grain yield $(\mathrm{kg} / \mathrm{ha})$

\begin{tabular}{|c|c|c|c|c|c|c|c|c|c|c|}
\hline \multicolumn{11}{|c|}{ MS } \\
\hline SV & $\mathrm{DF}$ & M.C.T. ${ }^{1}$ & W.A.I. ${ }^{1}$ & Chalk. $^{1}$ & I.G.P. $^{1}$ & Lenght & Width. & A.A.C. ${ }^{1}$ & G.T. ${ }^{1}$ & Yield \\
\hline Treatments & 13 & $7.39^{* *}$ & $0.02^{\mathrm{ns}}$ & $188.65^{* *}$ & $481.24^{* *}$ & $0.59^{* *}$ & $0.05^{* *}$ & $3.72^{* *}$ & $0.27^{* *}$ & $1919775.43^{* *}$ \\
\hline Location & 3 & $5.46^{* *}$ & $0.63^{* *}$ & $40.83^{* *}$ & $2101.77^{* *}$ & $0.79^{* *}$ & $0.27^{* *}$ & $12.67^{* *}$ & $1.54^{* *}$ & $40721009.73^{* *}$ \\
\hline Treat.*Locat. & 39 & $3.04^{* *}$ & $0.03^{* *}$ & $33.12^{* *}$ & $189.42^{* *}$ & $0.09^{* *}$ & $0.04^{* *}$ & $2.14^{* *}$ & $0.08^{* *}$ & $1205959.17^{* *}$ \\
\hline Rep(locat.) & 8 & $1.39^{* *}$ & $0.01^{\mathrm{ns}}$ & $7.87^{\mathrm{ns}}$ & $63.13^{* *}$ & $0.04^{* *}$ & $0.02^{* *}$ & $3.34^{* *}$ & $0.04^{* *}$ & $445479.51^{\mathrm{ns}}$ \\
\hline Error & 104 & $0.52^{\text {ns }}$ & $0.02^{\mathrm{ns}}$ & $11.45^{\mathrm{ns}}$ & $30.76^{\mathrm{ns}}$ & $0.04^{\mathrm{ns}}$ & $0.02^{\mathrm{ns}}$ & $1.06^{\mathrm{ns}}$ & $0.05^{* *}$ & $347137.06^{\mathrm{ns}}$ \\
\hline $\mathrm{CV}(\%)$ & & 3.3 & 7.04 & 46.68 & 16.36 & 2.87 & 7.24 & 4.75 & 5.48 & 17.12 \\
\hline $\operatorname{rgg}(\%)$ & & 76.15 & 81.24 & 90.50 & 77.84 & 92.24 & 70.29 & 74.01 & 84.20 & 70.82 \\
\hline Mean & & 21.8 & 1.8 & 5.9 & 33.8 & 6.7 & 2.0 & 21.7 & 4.1 & 3441.9 \\
\hline
\end{tabular}

Note. ${ }^{* *}$ significant, ${ }^{\mathrm{ns}}$ not significant at $5 \%$ probability by the $\mathrm{F}$ test.

${ }^{1}$ M.C.T: Minimum cooking time; W.A.I: water absorption index; Chalk.: Chalkiness; I.G.P.: integer grain percentage; A.A.C: apparent amylose content; G.T: gelatinization temperature.

Pearson correlation coefficients were obtained for the study of the relations and interferences of between the characteristics.

Table 3. Pearson correlation coefficients for the evaluated characteristics considering the joint analysis of the data

\begin{tabular}{|c|c|c|c|c|c|c|c|c|c|}
\hline & M.C.T. $^{1}$ & W.A.I. ${ }^{1}$ & Chalk. $^{1}$ & I.G.P. $^{1}$ & Yield & Lenght & Width & A.A.C. ${ }^{1}$ & G.T. $^{1}$ \\
\hline M.C.T. ${ }^{1}$ & 1 & -0.1336 & 0.0739 & 0.1334 & $-0.478^{3^{*}}$ & -0.3431 & 0.1534 & $-0.6136^{* *}$ & $-0.4446^{*}$ \\
\hline W.A.I. ${ }^{1}$ & & 1 & -0.2393 & 0.1676 & -0.172 & 0.0479 & 0.0308 & 0.3041 & 0.2939 \\
\hline Chalk. ${ }^{1}$ & & & 1 & -0.246 & 0.1003 & $0.4821^{*}$ & $0.4418^{*}$ & 0.1511 & 0.0777 \\
\hline I.G.P. ${ }^{1}$ & & & & 1 & 0.0812 & -0.3949 & $-0.5672^{* *}$ & 0.0795 & -0.3332 \\
\hline Yeld & & & & & 1 & 0.0452 & 0.0003 & $0.593^{* *}$ & 0.1529 \\
\hline Lenght & & & & & & 1 & $0.4409^{*}$ & 0.3503 & 0.303 \\
\hline Width & & & & & & & 1 & 0.0846 & $0.4364^{*}$ \\
\hline A.A.C. ${ }^{1}$ & & & & & & & & 1 & $0.6888^{* *}$ \\
\hline G.T. ${ }^{1}$ & & & & & & & & & 1 \\
\hline
\end{tabular}

Note. ${ }^{*}$ significant at $5 \%,{ }^{* *}$ significant at $1 \% .{ }^{1}$ M.C.T: Minimum cooking time; W.A.I: water absorption index; Chalk.: Chalkiness; I.G.P.: integer grain percentage; A.A.C: apparent amylose content; G.T: gelatinization temperature.

There is a significant and positive correlation between the apparent amylose content and the gelatinization temperature (Table 3), which is expected since amylose is a determinant of the cooking characteristics. There is a significant and positive correlation between minimum cooking time amylose contents and the gelatinization temperature. Since the scale of grades is reciprocal, negative values indicate a positive correlation. This can be a useful tool for breeding programs to infer about the behavior of one characteristic using the results of another, carrying out an indirect selection and reducing the number of analyzes required for the selection.

Table 4 shows the selected lines for each index and also the direct selection. Sample CMG 2119 was selected in all indexes and also in the direct selection. This demonstrates that, in addition to having good productivity, it meets the requirements for grain quality. 
Table 4. Identification of the four best performance lines by the Base, Rank and $\mathrm{Z}$ indexes and also by Direct Selection

\begin{tabular}{lllll}
\hline Classification & Base & Ranks & Z Index & Direct Selection \\
\hline $1^{\text {st }}$ & CMG 1896 & CMG 2119 & BRS Esmeralda & CMG 1896 \\
$2^{\text {nd }}$ & CMG 2119 & CMG 2188 & CMG 2188 & CMG 2119 \\
$3^{\text {rd }}$ & CMG 2085 & BRS Esmeralda & CMG 2185 & CMG 2085 \\
$4^{\text {th }}$ & CMG 1511 & CMG 2185 & CMG 2119 & CMG 2188 \\
\hline
\end{tabular}

Table 5 shows the coincidence percentages between indexes and direct selection. It is possible to notice that the $\mathrm{Z}$ and Rank indexes selected exactly the same lines. Reis et al. (2015) with eucalyptus and Lima (2015) with beans, also observed a high coincidence between the $\mathrm{Z}$ and Rank indexes. The base index coincided in only one strain $(25 \%)$.

Table 5. Percentage of coincidence between the indexes of selection and direct selection considering the four best lines selected in each index

\begin{tabular}{lllll}
\hline \multirow{2}{*}{ Selection Index } & \multicolumn{4}{c}{ Coincidence Index (\%) } \\
\cline { 2 - 5 } & Base & Ranks & Z & Direct Sel. \\
\hline Base & - & 25 & 25 & 75 \\
Ranks & - & - & 100 & 50 \\
$Z$ & - & - & - & 50 \\
\hline
\end{tabular}

Table 6 presents estimates of the percentages of the gains obtained with the selection for each index and with the direct selection for each characteristic. It was also calculated the sum of positive and negative gains with the selection according to each characteristic. The minimum cooking time, chalkiness, and width presented their best results expressed in lower values; therefore, the negative values indicate that there was gain for these characteristics. For the others, the negative values indicate negative gains, demonstrating the difficulty of gathering only good characteristics in a material. Regarding grain yield, the Base Index and Direct Selection provided the highest gains. However, despite this gain in productivity, these indexes presented losses in the quality characteristics, mainly considering chalkiness and integer grain percentage.

Table 6. Selection gains for Base, Rank and Z indexes and with Direct Selection considering the four best lines selected in each index

\begin{tabular}{lllllllll}
\hline \multirow{2}{*}{ Index } & \multicolumn{7}{c}{ Selection Gain (\%) } \\
\cline { 2 - 9 } & M.C.T.1 & W.A.I1 & Chalk.1 & I.G.P.1 & Length & Width & Yield & Sum \\
\hline Base & -0.10 & -0.06 & 8.75 & -2.28 & 0.36 & 0.39 & 4.20 & $(-6.82)$ \\
Rank & -1.43 & -0.08 & -11.34 & 1.32 & -0.30 & -0.73 & 2.04 & $(16.48)$ \\
Z & -1.43 & -0.08 & -11.34 & 1.32 & -0.30 & -0.73 & 2.04 & $(16.48)$ \\
Dir. Sel. & -0.75 & -0.58 & 13.97 & 0.01 & 0.71 & 0.14 & 4.23 & $(-10.2)$ \\
\hline
\end{tabular}

Note. ${ }^{1}$ M.C.T: Minimum cooking time; W.A.I: water absorption index; Chalk.: Chalkiness; I.G.P.: integer grain percentage.

In addition, the $\mathrm{Z}$ Index can be subjected to graphical performance analysis, as shown in Figure 1, where the graphs of the four best and the four worst lines are arranged. This is a differential of this index because it facilitates the vision of the performance of the lines in general. For example, the best performance lines or "full balls" are more uniform and larger in comparison to the general average, as in the case of lines 3,9, 7, and 5. The opposite is also valid, the lower performance lines or "withered balls" are lower than the general mean, as in the case of lines $6,13,4$, and 2 . 

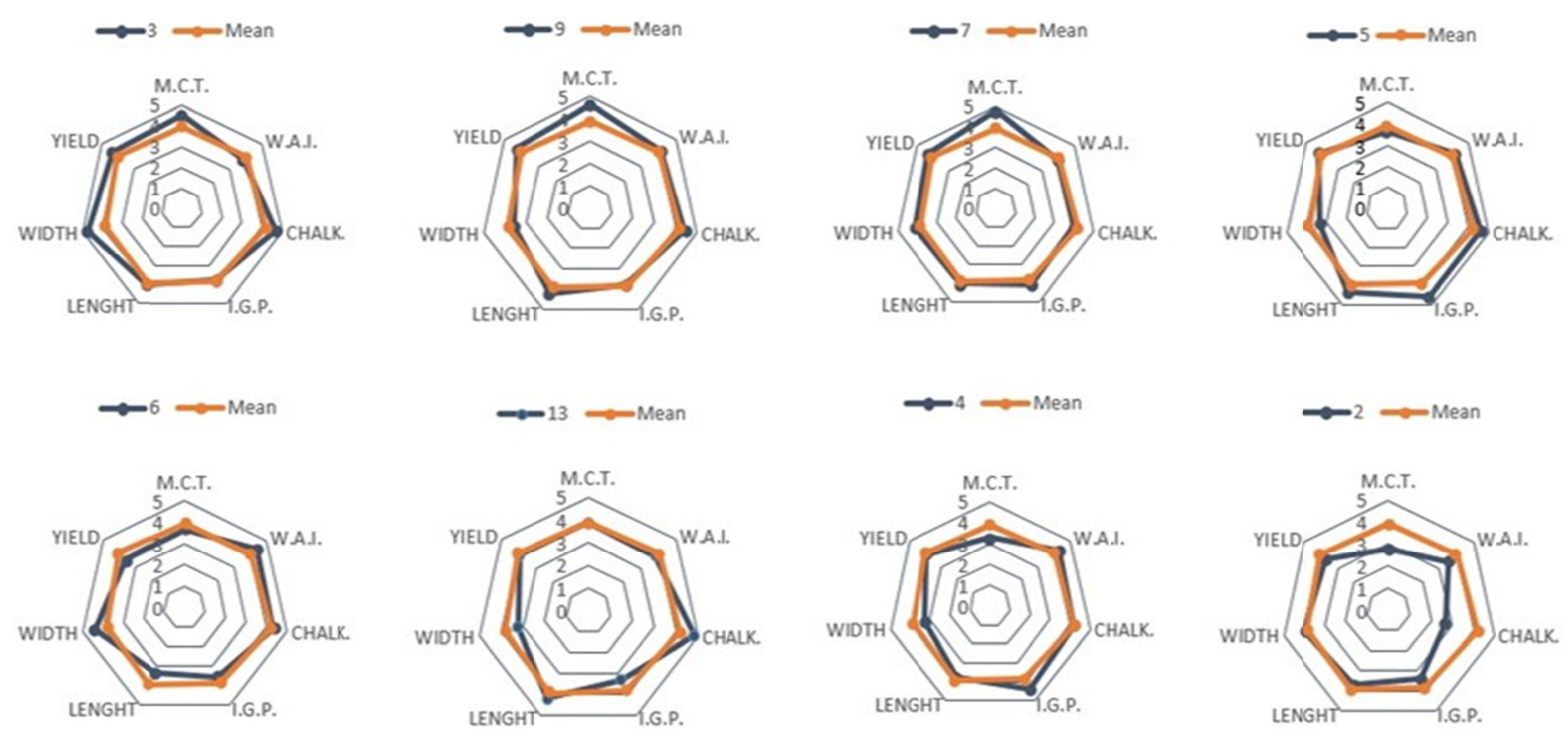

Figure 1. Graphical representation of the standard values of the characteristics: minimum cooking time (minutes), water absorption index, chalkiness (\%), integer grain percentage (\%), grain length and width (mm), apparent amylose content $(\%)$, gelatinization temperature (scores) and grain yield $(\mathrm{kg} / \mathrm{ha})$ of the four best and worst lines for the Z Index

\section{Discussion}

Regarding the water absorption index, there were no significant differences between the values, which were around 2.0 (200\%). The results are similar to those found by Arns et al. (2014). The rice grain when absorbing more water has a greater increase of its volume and probably greater softness after cooking. The highest estimates are associated to the most promising genotypes for recommendation in the market.

The percentage of grains varied from $1.4 \%$ to $13.4 \%$. The chalkiness process in some countries, such as Brazil, is considered a defect. As for Spain and Italy, it is valued commercially. The chalkined grain is characterized when it loses translucency due to changes in the structure of the endosperm starch. For the industry, this type of grain can cause a higher percentage of broken grains during the beneficiation phases and thus affect the framing in differentiated types of grains, devaluing the product for commercialization (Franco et al., 2011). The consumer market is very demanding regarding the translucency of the endosperm. In general, Type 1 rice, of better quality, should have a maximum of $2.0 \%$ of chalkiness (MAPA, 2012).

Integer grain percentage refers to the percentage of whole rice grains in a given sample or batch. The lowest estimate was $25.8 \%$ and the highest was $47.1 \%$, confirming the existence of significant differences between lines (Table 5). The percentage of integer grains is of extreme importance in the economic return of the crop. The rice grain can be broken in the beneficiation for several reasons. Some are inherent to the grain genetics itself and others are related to the handling and type of equipment used in the process. Small increases of $1 \%$ or $2 \%$ in yield generate significant values when considering the large grain yield (CONAB, 2015).

The rice grain can be classified into four different classes according to their size: long-thin, long, medium, and short. For rice to be considered long-thin, the grains must have a length of $6 \mathrm{~mm}$ or greater and a thickness of less than or equal to $1.9 \mathrm{~mm}$, with a length/width ratio greater than 2.75 . However, as an operational alternative, grains that obtain the adequate ratio and width smaller than $2.17 \mathrm{~mm}$ are automatically classified as long-thin (MAPA, 2012).

The Brazilian consumer market has a preference for long-thin rice (CONAB, 2015); thus, it is the most commercialized grain in the country and the focus of breeding programs. All the evaluated lines were classified as long-thin. The grains considered for selection were those that obtained the highest values for length and smaller for width.

For the apparent amylose content, the following classification is considered: glutinous grains (0-4\%), very low amylose (5-12\%), low (12-20\%), intermediate (20-25\%), and high (25-30\%) (Juliano, 2003). Higher amylose contents cause grains to be to dry and loose, which may harden after cooling. When the contents are lower, the 
grains are soft, watery and sticky to each other after cooking (Bao, Sun, \& Corke, 2007). The Brazilian consumer expects fast cooking, where the grains expand well in volume and are loose, dry, and soft after cooking. Moreover, after cooled and reheated, these standards are generally maintained when there is an intermediate amylose content (CONAB, 2015; Mingotte, Hanashiro, \& Fornasieri Filho, 2012). In the present study, considering the characteristic in question, there was a significant difference between lines, but all were classified as intermediate ( $20 \%$ to $25 \%$ of amylose), being in agreement with the national preference, being the lowest observed content of $20.8 \%$ and the highest $22.5 \%$.

The gelatinization temperature is also separated by classes, as follow: high, intermediate, and low. The Brazilian market has a preference for the middle class (scores 3 and 4). All studied lines met this criterion, with values varying from 3.8 to 4.2 . As the values of amylose content and gelatinization temperature were separated into classes and all the lines obtained the same classification, the two characteristics were not used in the calculation of the Selection Indexes.

Meeting the standards demanded by the consumer and the Brazilian industry is indispensable. However, a given rice strain will only be successful and indicated to the producer if associated to high grain yield. The studied lines obtained a significant difference in relation to grain yield, with an average of $3441.9 \mathrm{~kg} / \mathrm{ha}$, which is higher than the national average of productivity in the highlands $2169.0 \mathrm{~kg} / \mathrm{ha}$ (CONAB, 2017). All lines had average estimates higher than the national average productivity.

In the recommendation of rice lines, genotypes should possess a series of desirable characteristics in relation to physical, industrial, and chemical quality as well as good yields. In order for none of these attributes to be left aside, one option is to use the simultaneous selection of the characteristics involved by the use of Selection Indexes. In this study, three indexes were used: Base Index (Williams, 1962), Rank Index (Mulamb \& Mock, 1978 ) and $\mathrm{Z}$ index. For performance comparison with indexes, the direct selection considered only the values of grain yield.

The direct selection also shows that CMG 2188 was selected in two other indexes and that CMG 2085 and CMG 1896 , despite good productivity, were not well evaluated in relation to grain quality.

The BRS Esmeralda and CMG 2185 lines presented intermediate level yields, but were selected by two indexes, showing that their other characteristics stood out and raised their rank in the $\mathrm{Z}$ and Rank indexes.

The Base Index presented $75 \%$ coincidence with the direct selection due to the strong influence of the characteristic. Grain productivity in $\mathrm{kg} / \mathrm{ha}$ exerts a high influence on the other characters of smaller scale, a problem that does not exist in the Rank and $\mathrm{Z}$ indexes since their scales are dimensionless (Ramalho et al., 2012).

The Base Index and the Direct Selection showed a high coincidence between them, which was low in relation to the Rank and $\mathrm{Z}$ indexes, leading to the selection of cultivars with good yields and grain quality (CMG 2188 and CMG 2119). However, CMG 2185 and BRS Esmeralda were selected because they had good grain quality. Two of the most productive cultivars (CMG 1896 and CMG 2085) selected by direct selection did not present the best quality characteristics and were not selected in the Rank and $\mathrm{Z}$ indexes.

Vivas et al. (2013) with papaya and Freitas Junior (2009) with corn showed good results using the Rank Index. Oliveira et al. (2008) with passion fruit and Rezende et al. (2014) with coffee also observed good results with the $\mathrm{Z}$ Index. These authors also showed that the Base Index obtained better performance when used to select characteristics such as productivity, similar to that observed in Vivas et al. (2013) with papaya.

In the literature, different results for the evaluation of index efficiency are found because of the different type and number of material, the number of characteristics, the use or not of economic weights, and the generation of the population, used in the studies (Bernardo, 2002; Ramalho et al., 2012).

The $\mathrm{Z}$ and Rank indexes presented the same gains, since they selected the same lines. When only grain yield is considered, the gain was lower than the direct selection and the base index. However, considering the sum of the gains of all the characteristics, the indexes were higher, evidencing a better selection for grain quality characteristics. The differences, when comparing the estimates of genetic gains obtained with the Direct Selection and the estimates using indexes was also evident in the study of Vasconcelos et al. (2010) with alfalfa.

According to Terres et al. (2015), when using selection indexes it is possible to obtain a more homogeneous percentage distribution of gains for all the characteristics, unlike Direct Selection that provides maximization of the individual gains, which does not allow the obtention of satisfactory levels for the other characteristics. The Rank and $\mathrm{Z}$ indexes are considered easy to apply, since they do not require the elaboration of matrices of genetic variances and covariances, besides not using economic weights to their characteristics (Ramalho et al., 2012). In 
the present study, it was found that the genetic variation of the genetic variation was not significant. In addition, according to Rodrigues et al. (2011), the rank index facilitates the decision of the breeder regarding the genotypes to be selected and/or discarded.

\section{Conclusions}

The Rank and Z Indexes are more efficient in the selection of lines with desirable characteristics for grain quality in upland rice since they show higher and more balanced gains with high coincidence. The Base Index is efficient only for selection of grain yield, being highly coincident with the Direct Selection by the productivity, not obtaining desirable results in the selection for the quality of the rice grains.

The lines CMG 2119 and CMG 2188 obtained the best results for grain quality and yield, being selected by the indexes and also by the direct selection considering the productivity.

\section{Acknowledgements}

The authors would like to thank the funding agencies CAPES and FAPEMIG of the Brazilian government and Embrapa for the partial financial support for the research in this paper. We took the opportunity to inform you that there was no conflict of interest.

\section{References}

Arns, B. (2014). The effects of heat-moisture treatment of rice grains before parboiling on viscosity profile and physicochemical properties. International Journal of Food Science and Technology, 49(8), 1939-1945. https://doi.org/10.1111/ijfs. 12580

Bernardo, R. (2002). Breeding for quantitative traits in plants (p. 368). Woodbury: Stemma.

Ciacco, C. F., \& Chang, Y. K. (1986). Como fazer massas (p. 127). Campinas: UNICAMP.

CONAB (Companhia Nacional de Abastecimento). (2015). A cultura do Arroz (p. 180). Brasília.

CONAB (Companhia Nacional de Abastecimento). (2017). Acompanhamento da safra brasileira de grãos: Terceiro levantamento (Safra 2017/2018). Brasília.

Cruz, C. D. (2001). Programa Genes: versão Windows: Aplicativo computacional em genética e estatística (p. 648). Viçosa, MG: Editora UFV.

Cruz, C. D., Regazzi, A. J., \& Carneiro, P. C. S. (2012). Modelos biométricos aplicados ao melhoramento genético (4th ed., p. 508). Viçosa, MG: UFV.

Donnely, B. J. (1979). Pasta products: raw material, technology, evaluation. Macaroni Journal, 61(1), 6-18.

Franco, D. F. (2011). Qualidade do grão formado no colmo principal e nos perfilhos de plantas de arroz (Oryza sativa, 1.) em função de diferentes arranjos de distribuição de plantas no solo. Revista Brasileira de Agrociência, 17(1/4), 78-84.

Freitas Júnior, S. P. (2009). Predição de ganhos genéticos na população de milho-pipoca UNB-2U sob seleção recorrente utilizando-se diferentes índices de seleção. Semina, 30, 803-814. https://doi.org/10.5433/ 1679-0359.2009v30n4p803

Hamblin, J. E., \& Zimmermann, M. J. O. (1986). Breeding common bean for yield in mixtures. Plant Breeding Reviews, 4, 245-272. https://doi.org/10.1002/9781118061015.ch8

Hazel, L. N. (1943). The genetic basis for constructing selection indexes. Genetics, 28, 476-490.

Hummel, C. (1966). Macaroni products, manufacture, processing and packing (2nd ed., p. 287). London: Food Trade.

Juliano, B. O. (2003). Rice chemistry and quality (p. 480). Philippines: Philippine Rice Research Institute.

Lima, D. C. (2015). Breeding common bean populations for traits using selection index. Scientia Agricola, 72(2), 132-137. https://doi.org/10.1590/0103-9016-2014-0130

MAPA (Ministério da Agricultura, Pecuária e Abastecimento). (2012). Instrução Normativa $n^{\circ} 02$, de 6 de Fevereiro de 2012.

Martinéz, C., \& Cuevas, F. (1989). Evaluación de la calidad culinária y molinera del arroz: Guia de estúdio para ser usada como complemento de la unidad auditutorial sobre el mismo tema (3rd ed., p. 73). Cali: Centro Internacional de Agricultura Tropical. 
Mingotte, F. L. C., Hanashiro, R. K., \& Fornasieri Filho, D. (2012). Características físico-químicas do grão de cultivares de arroz em função da adubação nitrogenada. Semina: Ciências Agrárias, 33, 2605-2618. https://doi.org/10.5433/1679-0359.2012v33Supl1p2605

Mulamba, N. N., \& Mock, J. J. (1978). Improvement of yield potential of the Eto Blanco maize (Zea mays L.) population by breeding for plant traits. Egypt Journal of Genetics and Cytology, 7, 40-51.

Nunes, J. A. R., Ramalho, M. A. P., \& Abreu, A. F. B. (2005). Graphical method in studies of adaptability and stability of cultivars. Annual Report of the Bean Improvement Cooperative, 48, 182-183.

Ramalho, M. A. P. (2012). Aplicações da genética quantitativa no melhoramento de plantas autógamas (p. 522). Lavras: Universidade Federal de Lavras, Lavras.

Reis, C. A. F. (2015). Estratégias na seleção de simultânea de vários caracteres no melhoramento de eucalyptus. Ciência Florestal, 25(2), 457-467. https://doi.org/10.5902/1980509818465

Rodrigues, F. (2011). Índice de seleção e estimativa de parâmetros genéticos e fenotípicos para características relacionadas com a produção de milho-verde. Ciência e Agrotecnologia, 35, 278-286. https://doi.org/10.159 0/S1413-70542011000200007

Smith, H. F. A. (1936). Discriminant function for plant selection. Annals of Eugenics, 7, 240-250. https://doi.org/ 10.1111/j.1469-1809.1936.tb02143.x

Terres, L. R. (2015). Estimativas de ganhos genéticos por diferentes índices de seleção em três populações híbridas de batata. Horticultura Brasileira, 33(3), 305-310. https://doi.org/10.1590/S0102-0536201500003 00005

Vasconcelos, E. S. (2010). Estimativas de ganho genético por diferentes critérios de seleção em genótipos de alfafa. Revista Ceres, 57(2), 205-210. https://doi.org/10.1590/S0034-737X2010000200011

Vivas, M. (2013). Predição de ganhos genéticos e seleção de progênies de mamoeiro para resistência à pinta-preta. Tropical Plant Pathology, 38(2), 142-148. https://doi.org/10.1590/S1982-56762013000200008

Williams, J. S. (1962). The evaluation of a selection index. Biometrics, 18, 375-393. https://doi.org/10.2307/2 527479

\section{Copyrights}

Copyright for this article is retained by the author(s), with first publication rights granted to the journal.

This is an open-access article distributed under the terms and conditions of the Creative Commons Attribution license (http://creativecommons.org/licenses/by/4.0/). 